\title{
Heavy metals mobility in full-scale bioreactor landfill: Initial stage
}

\author{
Xian $\mathrm{Qu}{ }^{\mathrm{a}}$, Pin-Jing $\mathrm{He}^{\mathrm{a}, *}$, Li-Ming Shao ${ }^{\mathrm{a}}$, Duu-Jong Lee ${ }^{\mathrm{b}}$ \\ a State Key Laboratory of Pollution Control and Resource Reuse, Tongji University, Shanghai, 200092, PR China \\ b Chemical Engineering Department, National Taiwan University, Taipei 10617, Taiwan
}

Received 3 April 2007; received in revised form 12 July 2007; accepted 12 July 2007

Available online 27 August 2007

\begin{abstract}
Selected heavy metals (HMs) including $\mathrm{Cd}, \mathrm{Cr}, \mathrm{Cu}, \mathrm{Ni}, \mathrm{Pb}$ and $\mathrm{Zn}$ initially released from a full-scale bioreactor landfill were monitored over the first 20 months of operation. At the initial landfill stage, the leachate exhibited high HMs release, high organic matter content (27000-43000 $\mathrm{g} \mathrm{l}^{-1}$ of TOC) and low $\mathrm{pH}$ (5-6). By the fifth month of landfilling, the methanogenic stage had been established, and HMs release was reduced below the Chinese National Standards. Total released HMs accounted for less than $1 \%$ of landfill deposited during the investigated period. Most landfill HMs were inorganic. Fourier-transform infrared (FT-IR) spectra data and model calculations using Visual MINTEQ indicated that humic substances strongly affected the mobility of organic fractions of HMs in the methanogenic landfill. The initial rates of HMs release could be enhanced by recycling the leachate back to bioreactor landfill, but the total quantity released may be reduced by early establishment of methanogenic stage in bioreactor landfill.
\end{abstract}

(C) 2007 Elsevier Ltd. All rights reserved.

Keywords: Heavy metals; Bioreactor landfill; Visual MINTEQ; Solid-phase fractionation; Humic substances

\section{Introduction}

At increased concentrations, heavy metals (HMs) in municipal solid waste landfill leachate can adversely affect human health (Bozkurt et al., 1999; Kjeldsen et al., 2002; Baun and Christensen, 2004; Li et al., 2006; Feng et al., 2007). The HMs in landfill leachate or in polluted groundwater have been speciated to those associated with colloidal particles or those in a dissolved form (Gounaris and Anderson, 1993; Baun and Christensen, 2004; Ward et al., 2005; Baumann et al., 2006). The affinity of HMs to humic substances depends on the intrinsic dissociation constants of the associated carboxylic acid groups and phenolic acid groups (Gustafsson and Berggren, 2005). The specific forms and the reactivity of the HMs in solid phase determine their leachability (Flyhammar, 1997; Krishnamurti and Naidu, 2002). Flyhammar (1997) and He et al. (2006a) fractionated particulate-bound HMs in landfill

\footnotetext{
* Corresponding author. Tel./fax: +862165986104.

E-mail address: solidwaste@mail.tongji.edu.cn (P.-J. He).
}

waste but could not determine the role of humic substances on the mobility of HMs (Filip et al., 1985). Krishnamurti and Naidu (2002) proposed a modified sequential extraction fractionation scheme for $\mathrm{Cd}, \mathrm{Cu}$ and $\mathrm{Zn}$ in soils which examined fractions with metal-organic complex binding sites.

Recent studies have revealed that less than $0.02 \%$ of HMs in landfills is leached out over 30 years of landfilling (Kjeldsen et al., 2002; Øygard et al., 2004). However, Lu et al. (1985) showed that although HMs tended to be leached out of fresh landfill, they later became largely immobilized. Flyhammar and Håkansson (1999) and Mårtensson et al. (1999) demonstrated that reduced $\mathrm{pH}$ of local suspension with oxygen intrusion in landfill enhances HMs mobilization. The large quantity of fatty acids produced at the initial phase of solid waste degradation, especially in landfill containing a high fraction of putrescible waste, can reduce leachate $\mathrm{pH}$ to $<6$ (He et al., 2006a) thus affecting HM mobility in landfills.

Bioreactor landfill technology has advanced rapidly in recent years. Landfill gas generation, pollutants in landfill leachate (such as chemical oxygen demand (COD), 
biological oxygen demand $\left(\mathrm{BOD}_{5}\right)$ and ammonia nitrogen $\left(\mathrm{NH}_{4}^{+}-N\right)$ and indices of waste degradation (such as cellulose to lignin ratio) have been monitored and compared with traditional sanitary landfill in both lab-scale and full-scale studies (Reinhart and Al-Yousfi, 1996; Caine et al., 1999; Reinhart et al., 2002; Agdag and Sponza, 2005; He et al., 2005; Huang et al., 2005; Benson et al., 2007). Erses and Onay (2003) found that more than $90 \%$ of HMs were immobilized after injecting artificial leachate with high HMs content into lab-scale methanogenic landfill layer. Hater et al. (2003) reported HMs concentrations of less than $1 \mathrm{mg}^{-1}$ in more than $90 \%$ of leachate samples collected in the first two years of landfill. However, the evolution of $\mathrm{HMs}$ in leachate over time, especially in large landfills, has not been addressed.

The presence of organic substances, particularly humic substances, affects the mobility of HMs in soils, peat bog, river sediment and aquifers (Wu et al., 2002; Schwab et al., 2005; Clemente and Bernal, 2006; Gondar et al., 2006; Kyziol et al., 2006; Doig and Liber, 2007; Evangelou et al., 2007). Humic substances exhibit strong affinity to heavy metal ions. Most research has focused on the effect of humic substances in leachate on HMs mobility (Baun and Christensen, 2004). Aulin and Neretnicks (1997) and Bozkurt et al. (2000) demonstrated the strong binding capacity of humic substances in solid waste on HMs; however, little experimental data, especially in field scale, has confirmed their hypothesis.

The theoretical long-term migration potential of landfill HMs has also been discussed. Bozkurt et al. (1999, 2000) considered the effects of binding capacity in sulfides and humic substances, sorption capacity in hydrous ferric oxides and $\mathrm{pH}$-buffering reactions on the leaching properties of landfill HMs, especially in the case of oxygen intrusion into the landfill after methane production has ceased. Multisurface mechanistic geochemical models, e.g., ORCHESTRA, have also been applied to elucidate chemical processes predictive of long-term release of HMs from landfill (Dijkstra et al., 2004; Dijkstra et al., 2006; van der Sloot et al. 2007). However, few studies have examined the initial stage of bioreactor landfill, which may involve large quantities of easily degradable waste, such as in MSW in China.

This study investigated the mobility of HMs in a fresh, full-scale bioreactor landfill by monitoring HMs levels in leachate, simulating HMs speciation in leachate using Visual MINTEQ, fractionating HMs and characterizing humic acids (HA) and fulvic acids (FA) in landfill waste.

\section{Materials and methods}

\subsection{Landfill site}

The tested bioreactor landfill (TBL) was in the Tianziling MSW Landfill in Hangzhou City, Zhejiang Province, China. The TBL is approximately $16000 \mathrm{~m}^{2}$ with a combined GCL-HDPE bottom liner, and has four layers of filled MSW. Each layer is 6-8 m thick, and 121000 tons of waste has been filled (49000 tons in the first layer filled August-November, 2004; 34000 tons in the 2nd layer filled June-August, 2005; 38000 tons in the 3rd and the 4th layers filled November-December, 2005). The leachate was withdrawn from the landfill via a layer of granular material and a series of leachate collection pipes under the landfill waste. Liquid flow meters were installed at the ends of the collection pipes to measure acumulated volume of discharged leachate. Horizontal leachate recirculation pipes were installed 1-4 m below the top surfaces of the 1st and the 4th layers. The final cover was a layer of geo-net, a $0.3 \mathrm{~m}$ compacted soil barrier layer and a $0.3 \mathrm{~m}$ topsoil layer. Fig. 1 displays the TBL profile.

Leachate recirculation was started shortly after the landfilling for each layer was completed. Before recirculation, the collected leachate was aerobically pre-treated in two sequential batch reactors, each $80 \mathrm{~m}^{3}$ in volume, and retention time varied between 4 and $20 \mathrm{~d}$ according to the organic loading of the influent leachate. Leachate from the landfill $\left(4-20 \mathrm{~m}^{3}\right)$ was introduced into each tank daily. Initial organic loading rate was $2-3 \mathrm{~kg} \mathrm{COD} \mathrm{m}^{-3} \mathrm{~d}^{-1}$ for each tank, and aeration was applied continuously for $20 \mathrm{~h}$ to maintain dissolved oxygen above $2.0 \mathrm{mg}^{-1}$. Aeration was then shut down $(3 \mathrm{~h})$ until the sludge fully settled. The supernatant was pumped out and collected in the subsequent tank. The supernatant was then recycled back to the landfill layers.

\subsection{Sampling and tests}

\subsubsection{Leachate}

Leachate samples were collected and stored in darkness at $4{ }^{\circ} \mathrm{C}$ with minimum exposure to surrounding air. The sampled leachates were filtered and monitored for COD, $\mathrm{BOD}_{5}, \mathrm{NH}_{4}^{+}-N$, sulfate $\left(\mathrm{SO}_{4}^{2-}\right)$, chlorine ion $\left(\mathrm{Cl}^{-}\right)$and phosphate $\left(\mathrm{PO}_{4}^{3-}\right)$ according to standard methods (Franson, 1998). The $\mathrm{pH}$ and redox potential (Eh) of the unfiltered leachate samples were analyzed with a portable meter $\left(\right.$ Acorn $^{\circledR} \mathrm{pH} 6$ Meter, OAKTON Instrument, USA). The total organic carbon (TOC) of leachate samples was measured by a TOC/TN analyzer (multi N/C 3000, Analytik Jena AG, Germany). The dissolved organic carbon (DOC) in the leachate samples were categorized as humic acid (HA) or fulvic acid (FA) using the methods described by $\mathrm{He}$ et al. (2006b), Christensen et al. (1998) and Thurman and Malcolm (1981). Portions of leachate samples were digested, in triplicate, with nitric acid and analyzed for metals content $(\mathrm{K}, \mathrm{Ca}, \mathrm{Na}, \mathrm{Mg}, \mathrm{Cd}, \mathrm{Cr}, \mathrm{Cu}$, $\mathrm{Ni}, \mathrm{Zn}, \mathrm{Fe}, \mathrm{Mn}$ and $\mathrm{Al}$ ) by an inductively coupled plasma-atomic emission spectrometer (ICP-AES, Optima 2100 DV, Perkin Elmer, USA). The ionic strength of the leachate was calculated by Visual MINTEQ.

\subsubsection{Solid waste}

The solid samples were collected from the 1st (W2) and the 4th layers (W1) of landfill, aged 1.5 and 0.5 years, respectively. To ensure the collected solid waste samples 


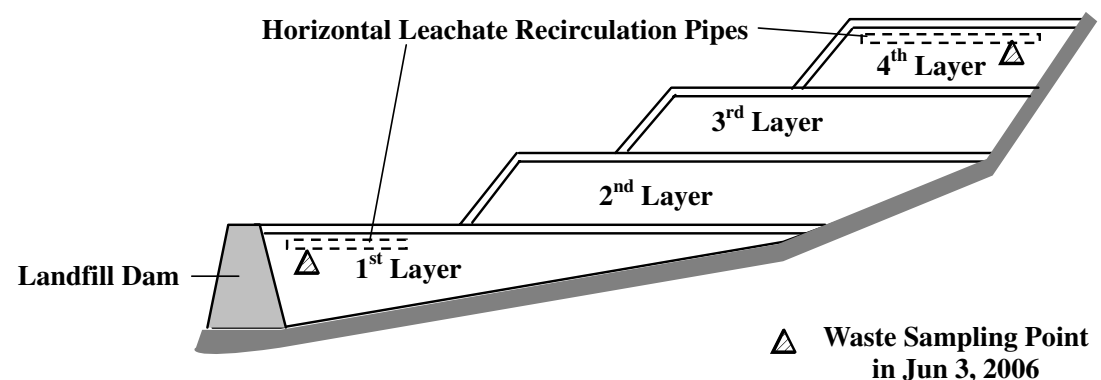

Fig. 1. Profile of the bioreactor landfill. Landfill operation in 1st Layer was carried out during Aug 2004-Nov 2004 (Phase I); landfill operation in 2nd Layer was carried out during Jun 2005 to Aug 2005 (Phase II); landfill operation in 3rd and 4th Layers was carried out during Nov 2005 to Dec 2006 (Phase III).

were representative of the TBL, each sample was taken from more than $100 \mathrm{~kg}$ of waste extracted from several sites at $1.5-2.5 \mathrm{~m}$ below the monitored landfill layer. The collected samples were stored in dark plastic bags at $4{ }^{\circ} \mathrm{C}$ immediately after sampling. Before analysis, the waste samples were air-dried, crushed and passed through a 2$\mathrm{mm}$ sieve. Large metal items as well as plastics, gravel and stones were removed from the sample.

Total heavy metals content was determined by digestion with $\mathrm{HCl}-\mathrm{HNO}_{3}-\mathrm{HF}-\mathrm{HClO}_{4}$ mixture followed by ICPAES (Optima 2100 DV, Perkin Elmer, USA) measurement.

The heavy-metal-binding forms in the solid phase were categorized into the following eight fractions by the sequential extraction method developed by Krishnamurti and Naidu (2002): exchangeable fraction, fraction bound to carbonates, metal-humic and fulvic complex-bound, easily reducible metal oxide-bound, organic-bound (defined as metals associated with organics other than humic and fulvic acids), amorphous mineral colloid-bound, crystalline $\mathrm{Fe}$ oxide-bound and fraction bound to $\mathrm{Al}-\mathrm{Si}$ minerals. Sequential extraction was performed in triplicate on $1 \mathrm{~g}$ of waste sample $(<2 \mathrm{~mm})$ in $50 \mathrm{ml}$ polypropylene centrifuge tubes to facilitate centrifuge washing of the soil after each extraction and to minimize any loss of solids. After each successive extraction, the supernatant was removed by centrifugation for $10 \mathrm{~min}$ at $12000 \mathrm{~g}$. The residue was washed twice with $10 \mathrm{ml}$ of deionized distilled water followed by centrifugation at $12000 \mathrm{~g}$ for $10 \mathrm{~min}$. The concentration of heavy metals in the separated extraction solutions were also measured by ICP-AES.

The fractions of HAs and FAs in solid phase were extracted from the waste samples in triplicate. For each waste sample (W1 and $\mathrm{W} 2$ ), $20 \mathrm{~g}$ waste samples and $200 \mathrm{ml}$ alkaline mixture of $0.1 \mathrm{M} \mathrm{Na} \mathrm{N}_{2} \mathrm{P}_{2} \mathrm{O}_{7}$ and $0.1 \mathrm{M}$ $\mathrm{NaOH}(1: 1 \mathrm{v}: \mathrm{v})$ were put in a plastic bottle. Before extraction, $\mathrm{O}_{2}$ was purged from the bottle by nitrogen gas injection for $10 \mathrm{~min}$. The bottle was then sealed and agitated at $25^{\circ} \mathrm{C}$ for $3 \mathrm{~h}$. The mixtures were then centrifuged for $15 \mathrm{~min}$, and the supernatant was filtered through a $0.45 \mu \mathrm{m}$ filtration membrane. The extraction procedure was repeated at least six times until the color of the supernatant lightened. All the supernatant were combined and acidified by $\mathrm{HCl}$ to $\mathrm{pH} 1.0$, left standing for $24 \mathrm{~h}$ in a refrig- erator to precipitate HAs then centrifuged to collect precipitates (HAs). The HAs were then dissolved in $0.1 \mathrm{M} \mathrm{NaOH}$ and adjusted to $\mathrm{pH} 7.0$ using $1 \mathrm{M} \mathrm{HCl}$. After removing HAs, the acidic filtrate containing the dissolved FA fraction was passed through a column of XAD-8 resin. The adsorbed FA was then recovered by elution with $0.1 \mathrm{M}$ $\mathrm{NaOH}$ and distilled water. The TOC of the HA and FA solutions was also tested.

The humic substances extracted from leachate were also characterized by Fourier-transform Infrared (FT-IR) spectra. Metals in this HA sample were removed by treatment with $\mathrm{HF}(0.3 \mathrm{M}) / \mathrm{HCl}(0.1 \mathrm{M})$ solution. The FA solutions were purified with 732 cation exchange resin (Shanghai Huizhi Co., Shanghai, China). After purification, the HA and FA solutions were individually freeze-dried and mixed into IR grade $\mathrm{KBr}$ powders at a mass ratio of 1:100 palletized under pressure. The FT-IR spectrometer (EQUINOX 55 spectrometer, Bruker, Germany) was used to acquire the FT-IR transmission spectra at a 64 scans with $4 \mathrm{~cm}^{-1}$ resolution and corrected for a $\mathrm{KBr}$ background.

\subsubsection{Landfill gas}

Landfill gas was pumped from the vertical perforated pipe system in the landfill by a slight vacuum $(<0.001 \mathrm{~atm})$. The volume of the produced landfill gas was also measured by a gas meter (2X-8A vane-type vacuum pump, Shanghai Boyi Pump Manufacturer, Co. Ltd., Shanghai, China) connected to the gas pump outlet. Landfill gas was also sampled weekly in triplicate with $10 \mathrm{ml}$ syringes. The methane and carbon dioxide concentrations in biogas were analyzed using a gas chromatograph (GC-14B, Shimadzu Corporation, Kyoto, Japan) equipped with a thermal conductivity detector. The operational temperatures of the injection port, the oven and the thermal conductivity detector were 110,100 and $230^{\circ} \mathrm{C}$, respectively. Nitrogen gas was used as the carrier gas at a flow rate of $60 \mathrm{ml} \mathrm{min}^{-1}$.

\subsection{Statistical analysis}

The SPSS v.13.0 (SPSS Inc., USA) software package was used for bivariate analysis of the following parameters: HMs concentration, $\mathrm{pH}, \mathrm{COD}$ and $\mathrm{NH}_{4}^{+}-N$ of leachate. 


\subsection{Modeling of HMs speciation in leachate}

The chemical equilibrium model Visual MINTEQ (version 2.40) was used to model the chemical speciation of $\mathrm{Cd}, \mathrm{Cr}, \mathrm{Cu}, \mathrm{Ni}, \mathrm{Pb}$ and $\mathrm{Zn}$ in the TBL leachate. Visual MINTEQ (version 2.40) is a Windows version of MINTEQA2 (version 4.0) released by the US EPA in 1999 which employs a chemical equilibrium model to calculate metal speciation and solubility equilibria in natural aqueous systems. Considering the difference in affinity of HA and FA to HMs, the Stockholm humic model (SHM) (Gustafsson and Berggren, 2005) was used to estimate the speciation of HMs bound to the humic substances in leachate. The default values of the metal-binding parameters in Visual MINTEQ were applied in this study. One hundred percent of dissolved organic matter (DOM) was assumed active to metal binding, and the active ratio of DOM to DOC was set as 2. The HA and FA concentrations and HA to FA ratios based on fractionation tests were the model input.
The fixed-ratio redox couples of $\left(\mathrm{Cr}(\mathrm{OH})_{2}^{+}\right) /\left(\mathrm{CrO}_{4}^{2-}\right)$ and $\mathrm{Cu}^{+} / \mathrm{Cu}^{2+}$ were examined. Table $\mathrm{S} 3$ in Supplementary material presents other input data for modeling the speciation scenarios for the leachate, including measured concentration of $\mathrm{Cd}, \mathrm{Cr}, \mathrm{Cu}, \mathrm{Ni}, \mathrm{Pb}, \mathrm{Zn}$ and other inorganic cations, anions and $\mathrm{pH}$ and $\mathrm{Eh}$ of the leachate.

\section{Results}

\subsection{Leachate characteristics}

The concentrations of HMs in leachate were high in the initial stage of landfilling (Fig. 2), particularly those of $\mathrm{Cd}, \mathrm{Cu}, \mathrm{Ni}, \mathrm{Pb}$ and $\mathrm{Zn}$, whose concentrations exceeded the Chinese National Standards (State Environmental Protection Administration of China, 1997). Following this stage, the concentrations of all heavy metals in leachate were reduced to low levels after 3-4 months of landfilling.

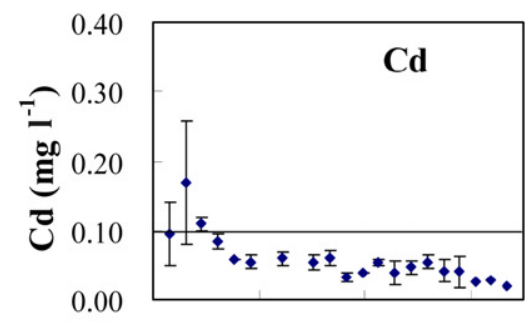

2004-08 2005-02 2005-09 2006-03 Time

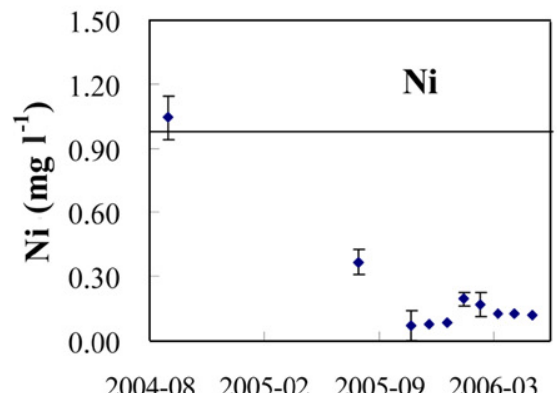

Time

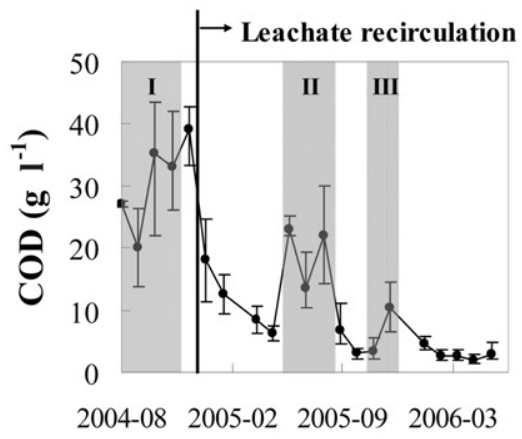

Time

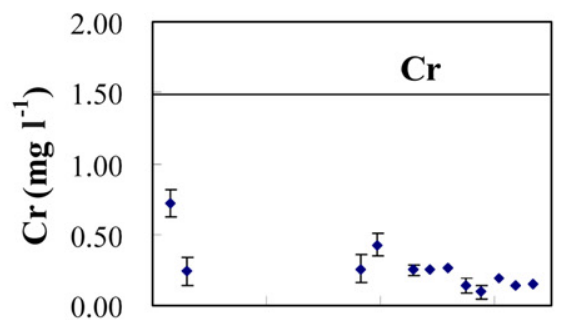

2004-08 2005-02 2005-09 2006-03

Time
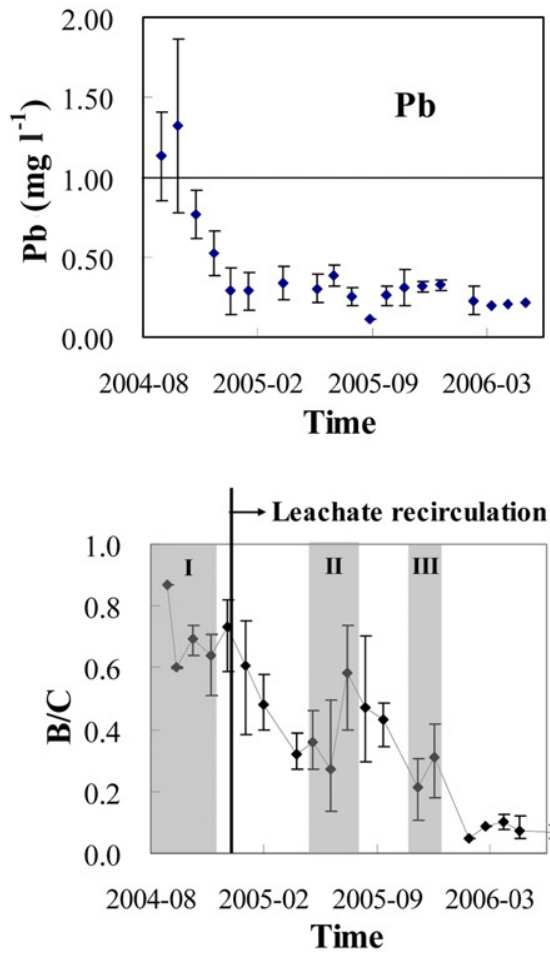

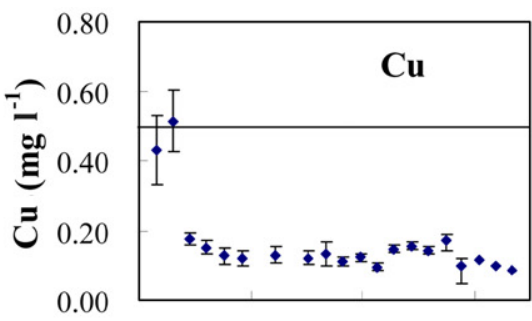

2004-08 2005-02 2005-09 2006-03 Time
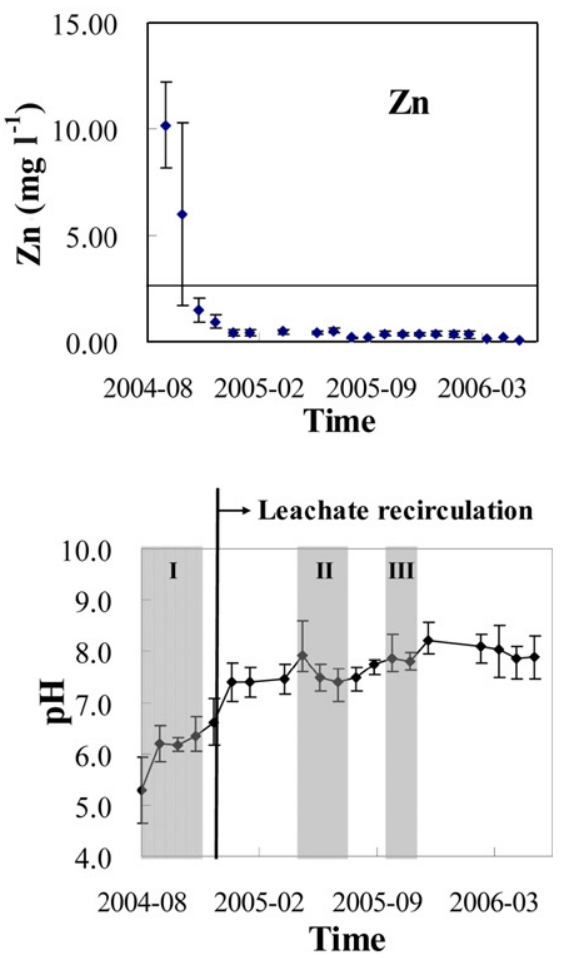

Fig. 2. Time evolution of $\mathrm{Cd}, \mathrm{Cr}, \mathrm{Cu}, \mathrm{Ni}, \mathrm{Pb}$, and $\mathrm{Zn}$ concentrations, $\mathrm{COD}, \mathrm{B} / \mathrm{C}$, and $\mathrm{pH}$ in the leachate. Landfill operation: 1st phase (I); 2nd phase (II); 3rd phase (III). The permitted concentration in the Chinese National Standards (State Environmental Protection Administration of China, 1997) was signed as "__ " in the figure. 
Table 1

DOC and humic substance in the leachate

\begin{tabular}{|c|c|c|c|c|c|}
\hline & \multirow{2}{*}{$\frac{\mathrm{DOC}}{\left(\mathrm{mg} \mathrm{l}^{-1}\right)}$} & \multicolumn{2}{|l|}{ HA } & \multicolumn{2}{|l|}{ FA } \\
\hline & & $\left(\mathrm{mg} \mathrm{C}^{-1}\right)$ & $(\%)$ & $\left(\mathrm{mg} \mathrm{C}^{-1}\right)$ & $(\%)$ \\
\hline $\begin{array}{c}\text { Leachate } \\
\text { from } \\
\mathrm{TBL}^{\mathrm{a}}\end{array}$ & $675 \pm 60$ & $35 \pm 20$ & $5.2 \pm 3.0$ & $260 \pm 30$ & $38.4 \pm 4.4$ \\
\hline $\begin{array}{l}\text { Fresh } \\
\quad \text { leachate }^{\mathrm{b}}\end{array}$ & 15200 & 87 & 0.6 & 3390 & 22.3 \\
\hline Leachate ${ }^{c}$ & 481 & 101 & 21.0 & 123 & 25.6 \\
\hline Leachate $^{\mathrm{d}}$ & 94 & 100 & 28.0 & 336 & 29.8 \\
\hline
\end{tabular}

a Sampled in May, 2006, landfill age 1.5 years.

${ }^{\mathrm{b}}$ He et al. (2006b), landfill age less than 1 year.

${ }^{c}$ Fan et al. (2006), from a landfill with age of 12 years.

${ }^{d}$ Fan et al. (2006), from a landfill with age of 11-17 years.

Table 2 lists the estimated leach-out quantities of HMs. According to the database for local fresh MSW (He et al., 2006 a), less than $1 \%$ of the landfilled HMs were leached out over the initial 20 months of landfilling.

The HA and FA content of each leachate component decreased with increasing landfill age (Table 1). Table 1 summarizes data collected from different landfills in China that receive MSW of similar composition. More than 20\% of the DOC in leachate was FA in the fresh leachate, and the ratios of HA to DOC in the leachate increased with landfill age.

\subsection{Solid waste characteristics}

The solid-phase fractionation of HMs in the solid phase was performed according to the sequential extraction procedures developed by Krishnamurti and Naidu (2002) (Fig. 3). The total HMs content estimated by summing the fractions from the sequential extraction procedures agreed with estimated total HMs directly digested (standard deviation $<5 \%$ ). Approximately $12 \%$ of $\mathrm{Cu}$ in exchangeable form in the solid waste at landfill age of 0.5 year (W1) was released in one year (W2). High K, Na, $\mathrm{Ca}$ and $\mathrm{Mg}$ concentrations in leachate (Table 1) may be favorable for converting this fraction of $\mathrm{Cu}$ (and those of $\mathrm{Cd}, \mathrm{Ni}$, and $\mathrm{Zn}$ ) into leachate. A large fraction of $\mathrm{Cr}$ and $\mathrm{Zn}$ in solids was in carbonate form. The high $\mathrm{CO}_{2}$ content (exceeding $40 \%$ ) in landfill gas could favorably carbonate the $\mathrm{HMs}$ (except $\mathrm{Cr}$ ). About $28 \%$ of $\mathrm{Cu}$ in the landfill waste aged 0.5 year was bound to organics, and the percent of metal-organic complexes was increased to $45 \%$ in landfill aged 1.5 years. Less than $7 \%$ of $\mathrm{Cr}, \mathrm{Ni}, \mathrm{Pb}$ and $\mathrm{Zn}$ were bound in metal-organic complex. Accordingly, these metals in leachate were slightly decreased over one year of landfilling. At a landfill age of 0.5 years, $15 \%$ of $\mathrm{Cr}, 25 \%$ of $\mathrm{Cu}, 14 \%$ of $\mathrm{Ni}, 30 \%$ of $\mathrm{Pb}$ and $36.6 \%$ of $\mathrm{Zn}$ in solids were associated with amorphous metal oxides and crystalline $\mathrm{Fe}$ oxides. At 1.5 years of filling age, these HMs were largely transformed into mineral forms or released with the landfill leachate. After the initial 1.5 years, most HMs were bound with alumino silicates (W2), which would increase their retention in the landfill.

The amounts of humic substances in solid phase were decreased, and the HA to FA ratio was increased significantly from 0.5 to 1.5 years of landfill age (Table 1). Fig. 4 shows the FT-IR spectra of HA and FA extracted from solid waste. Compared with the FA fraction, the HA fraction had stronger aliphatic bands (2922-2850 and 1464$\left.1375 \mathrm{~cm}^{-1}\right)$, more carboxylic groups $\left(1710-1725 \mathrm{~cm}^{-1}\right)$ (Mecozzi and Pietrantonio, 2006) and more bands of aromatic $\mathrm{C}=\mathrm{C}$ and/or secondary amides $\left(1514 \mathrm{~cm}^{-1}\right)$. Meanwhile, the HA in leachate was enriched with phenolic groups (1388-1414 $\mathrm{cm}^{-1}$ and $1259-1230 \mathrm{~cm}^{-1}$ ) (Shirshova et al., 2006). The HA contained aromatics or amides (1646 and $1546 \mathrm{~cm}^{-1}$ ), but the FA had none. The main HMs binding sites of humic substances include carboxylic acid sites and phenolic acid sites (Gustafsson and Berggren, 2005; Sawalha et al., 2007). Because the acidity of carboxylic acid was stronger than that of phenolic acid, the FA from the leachate and HA from the waste may have HMs with stronger binding capacity than that in FA from the landfill waste and HA from the leachate.

\section{Discussion}

\subsection{HMs leaching out in initial acidification stage and subsequent methanogenic stage}

The examined sample contained more than $60 \%$ of putrescible waste with moisture content exceeding $60 \%$. Hence, highly contaminated leachate was generated shortly

Table 2

Mass balance of heavy metals in the landfill

\begin{tabular}{|c|c|c|c|c|c|c|}
\hline & $\mathrm{Cd}$ & $\mathrm{Cr}$ & $\mathrm{Cu}$ & $\mathrm{Ni}$ & $\mathrm{Pb}$ & $\mathrm{Zn}$ \\
\hline Concentration in leachate $\left(\mathrm{mg} \mathrm{l}^{-1}\right)$ & $0.0005-0.258$ & $0.048-0.427$ & $0.0075-0.95$ & $0.12-0.584$ & $0.011-1.87$ & $0.063-10.3$ \\
\hline Total leachate volume $\left(\mathrm{m}^{3}\right)$ & 59100 & & & & & \\
\hline Total mass of metals in leachate $(\mathrm{kg})$ & 3.23 & 14.3 & 8.84 & 19.9 & 21.1 & 55.9 \\
\hline Total waste dumped in the landfill $(\mathrm{t}, \text { dry base })^{\mathrm{b}}$ & 59300 & & & & & \\
\hline Estimated heavy metal mass deposited $(\mathrm{t})$ & 0.33 & 5.94 & 2.75 & 2.56 & 13.19 & 20.24 \\
\hline
\end{tabular}

${ }^{\text {a }}$ Calculated based on the measured waste composition during the period of landfill operation and the metals content in every waste composition (He et al., 2006a).

${ }^{\mathrm{b}}$ Calculated based on the weight and the moisture content of the dumped waste (measured in wet base). 

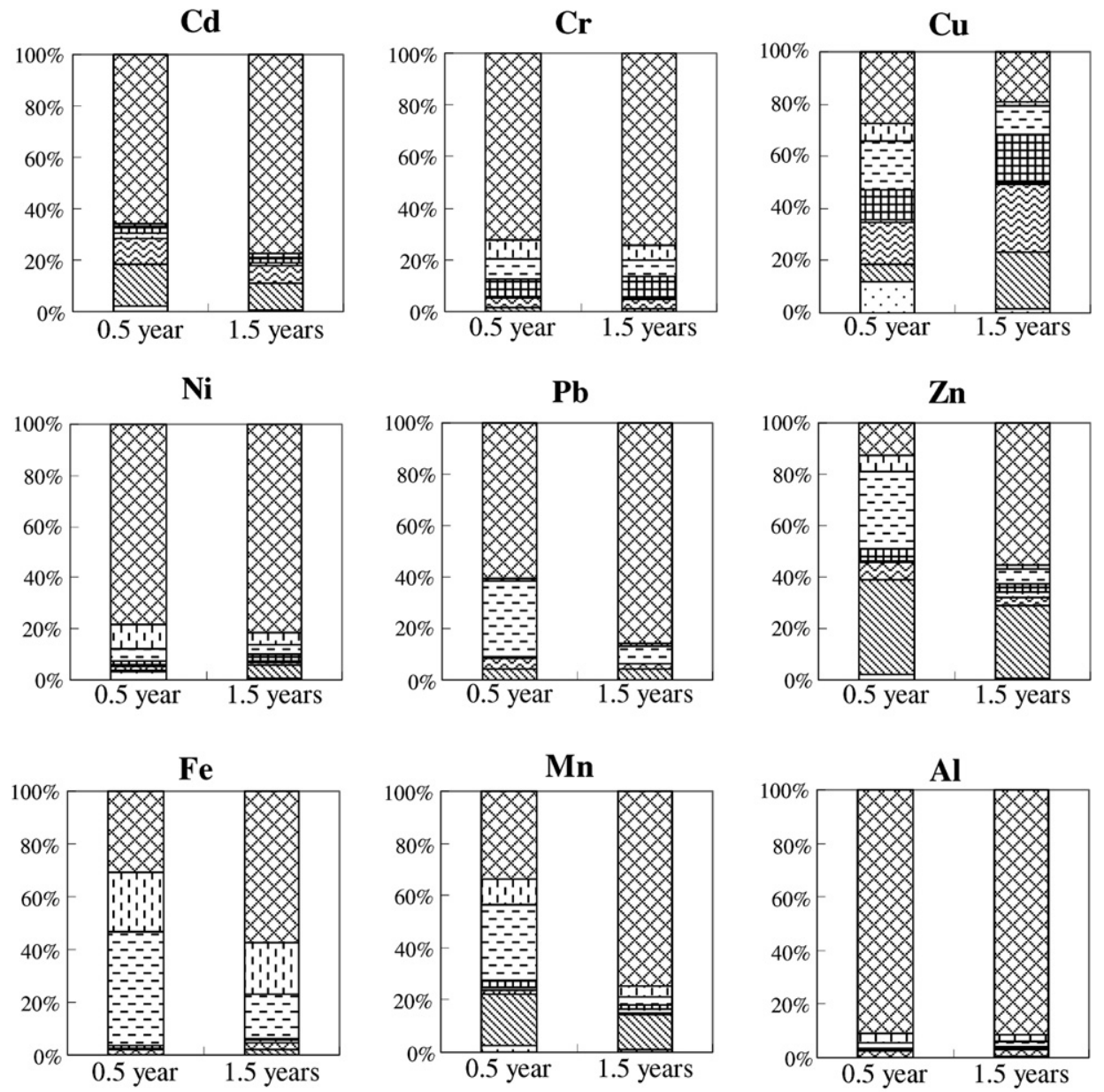

Exchangeable

$\mathbb{Q}$ Bound to carbonates

图 Metal-humic and fulvic complex-bound Easily reducible metal oxide-bound

田 Organic-bound

(4) Crystalline Fe oxide-bound

\section{G Amorphous mineral colloid-bound \\ Bound to Al-Si minerals}

Fig. 3. Sequential extraction of landfill wastes (W1 as 0.5 year and W2 as 1.5 years). The results are based on triplicate analysis, and the standard deviation is less than $5 \%$.

after landfilling, and COD concentration of leachate increased from 27000 to $40000 \mathrm{mg} \mathrm{l}^{-1}$, and $\mathrm{BOD}_{5}$ to COD ratio (B/C) increased $0.6-0.8$ (Fig. 2). Low leachate $\mathrm{pH}(5.0-6.0)$ and highly volatile fatty acid (VFA) levels (acetate $4500-7000 \mathrm{mg} \mathrm{l}^{-1}$, propionate $1450-2950 \mathrm{mg} \mathrm{l}^{-1}$ and butyrate $4500-7200 \mathrm{mg} \mathrm{l}^{-1}$ ) indicated that the landfill layer was in the acidification stage. The HMs concentrations were also high at this stage (Fig. 2). The HMs concentrations were significantly related to COD (Table S4 in Supplementary material). Earlier works revealed that various organic substances have high affinity for HMs (Christensen et al., 1999; Christensen and Christensen, 2000; Guibaud et al., 2003), which probably explains the noted correlation between the HMs release trend (Fig. 2) and levels of organic substances in the leachate.

When the first layer of landfilled MSW reached methanogenic stage (more than $500 \mathrm{~m}^{3}$ landfill gas per day with $50-60 \% \mathrm{CH}_{4}$ content, the corresponding COD in leachate declined to approximately $6500 \mathrm{mg}^{-1}$ while HMs concentrations also declined (Fig. 2). When the 2nd layer of MSW was filled above the 1st layer and the acidification stage, strong leachate with high content of biodegradable organics $(\mathrm{B} / \mathrm{C}>0.5)$ and HMs intruded downward. However, the HMs in the leachate collected at the bottom of the 1st layer remained low. Hence, the methanogenic 1st layer retained HMs intruding from the top, 2nd layer. Erses and Onay (2003) noted a similar result in their study using labscale reactors. Restated, the neutral to weakly alkaline condition in methanogenic stage probably corresponded to the low HMs in leachate since most HMs were in amphoteric forms with $\mathrm{pH}$-dependent solubility.

\subsection{Role of humic substances on HM mobility}

Thermodynamic models, particularly MINTEQA2, have been adopted to describe metals speciation in leachate 

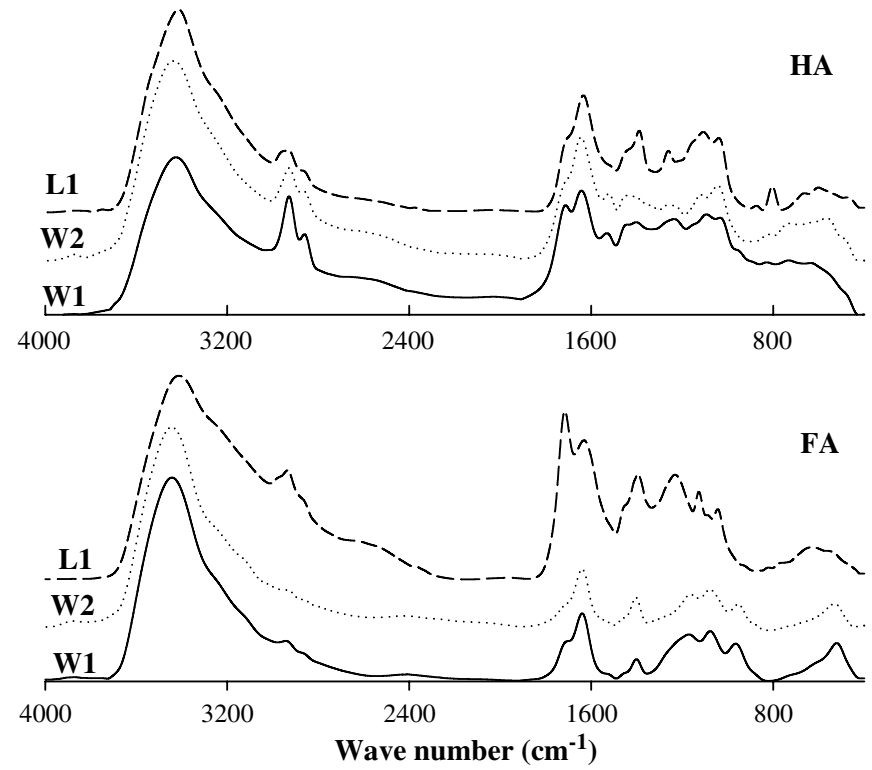

Fig. 4. Fourier-transform infrared (FT-IR) spectra in the range 4000$400 \mathrm{~cm}^{-1}$ for the freeze-dried HA and FA fractions from leachate (L1, sampled in May, 2006) and waste (W1 and W2).

(Christensen et al., 1999; Jensen et al., 1999; Christensen and Christensen, 2000; Guibaud et al., 2003). These works demonstrated that a large portion of HMs in leachate or in groundwater is bound to organic substances, assuming that the FA is the sole organic substance present in the system. The current study employed the Visual MINTEQ (version 2.40) program in conjunction with the Stockholm humic model (SHM) considering different affinity of HA and FA to HMs (Gustafsson and Berggren, 2005) to estimate HM speciation in leachate.

Computer modeling revealed that the $\mathrm{HA}$ and FA could strongly bind HMs (Table 3): Cd-FA and $\mathrm{Cd}-\mathrm{HA}, 93.8$ 95.1\%; Cr-FA and $\mathrm{Cr}-\mathrm{HA}, 100.0 \%$; $\mathrm{Cu}-\mathrm{FA}$ and $\mathrm{Cu}-\mathrm{HA}$, 100.0\%; Ni-FA and Ni-HA, 77.5-77.9\%; Pb-FA and Pb-HA, 99.6-99.7\%; Zn-FA and Zn-HA, 96.3-96.9\%, at a higher rate than calculated by Baun and Christensen (2004). This finding may be attributable to the higher $\mathrm{pH}$ and higher concentration of organic materials in the investigated leachate in comparison with other reports (Christensen and Christensen, 2000). Since the FA dominated each of the DOC fractions in leachate (Table 1), the leaching potentials for FA-HMs complexes leaching out were thereby high, particularly in the initial stage of landfill. This result may explain the high HM levels noted in initial landfill stages (Fig. 2). Meanwhile, FA solubility was higher than that of HA, which caused much higher HA/FA ratios in the waste than in the leachate. The HMs binding capacities of HA and FA in the leachate and the solid waste (discussed in 3.2) may indicate that the solubility of humic substances strongly influence HMs mobility.

\subsection{HMs bound to inorganic matter}

Sequential extraction of $\mathrm{Cu}$ and $\mathrm{Zn}$ speciation in soil by Krishnamurti and Naidu (2002) showed that more than $20 \%$ of $\mathrm{Cu}$ and $\mathrm{Zn}$ was associated with $\mathrm{HA}$ and FA.

Table 3

The calculated result of species distribution of $\mathrm{Cd}, \mathrm{Cr}, \mathrm{Cu}, \mathrm{Pb}$ and $\mathrm{Zn}$ in the leachate sample $\mathrm{L} 1$ by Visual MINTEQ

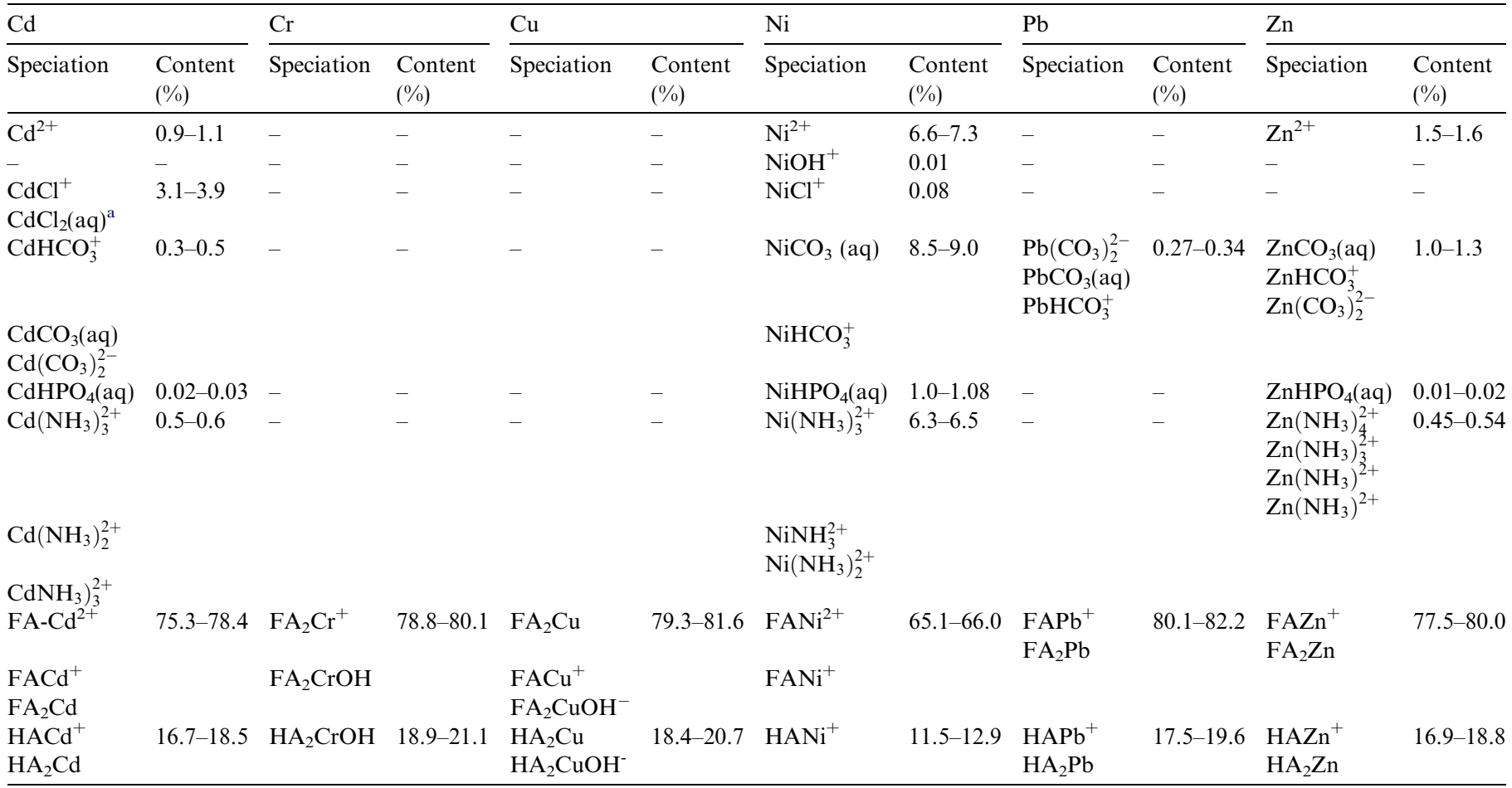

${ }^{\mathrm{a}}$ (aq): saturated in liquid phase. 
Dijkstra et al. (2004) also demonstrated the significance of humic substances on the complexation reaction of soil HMs. However, in this study, solid-phase HMs in the landfill waste were largely in metal-inorganic complexes except for $\mathrm{Cu}$. However, the humic content in the present TBL was quite high, 1.6-375 times that in landfills investigated in Germany and Spain (Filip et al., 1985; González-Vila et al., 1995), a consequence of the relatively high food waste fraction in the investigated TBL. Further study is required to clarify the inconsistencies between the present study and earlier findings. Nevertheless, the $\mathrm{Cd}, \mathrm{Cr}, \mathrm{Ni}$, $\mathrm{Pb}$ and $\mathrm{Zn}$ content associated with inorganic matter accounted for more than $80 \%$ of total HMs, indicating that the characteristics of HMs bound to inorganic matter and the associated $\mathrm{pH}$-buffering reactivity should predominantly control the long-term leaching potential of HMs (Bozkurt et al., 1999).

\subsection{Bioreactor landfill and HMs mobility}

Leachate recirculation in bioreactor landfill could accelerate degradation of organic waste. The enhanced rate of hydrolysis in bioreactor landfill waste could reduce the leachate pH to 6.5 (Benson et al., 2007) or even lower by directly recycling leachate without pretreatment, such as in the case of landfills examined in China ( $\mathrm{He}$ et al., 2007). The reduced leachate $\mathrm{pH}$ could increase HM mobility in initial landfill stages. However, with pretreated leachate recirculating in landfill, the methanogenic stage could be achieved much earlier (He et al., 2007), hence reducing total HM release from landfill. Leachate recirculation could also reduce HM release by returning the HMs to landfill, although the amount of recirculated leachate would be low. Meanwhile, the HMs could be immobilized by high acid neutralization potential with high $\mathrm{CO}_{2}$ partial pressure and high content of humic substances in rapidly established methanogenic stage in bioreactor landfill. Whether the application of bioreactor landfill affects HMs release in initial stage compared to the traditional sanitary landfill depends on how low the $\mathrm{pH}$ drops and on how fast the methanogenic stage is established.

\section{Acknowledgements}

The authors acknowledge the financial support given by the General and Key Programs of the National Natural Science Foundation of China (NSFC) (50578115 and 50538080), Hi-Tech Research and Development Program of China (HTRDP) (2001AA644010 and 2003AA644020) and National Sci \& Tech. Supporting Program of China (No. 2006BAC06B05 and No. 2006BAJ04A06).

\section{Appendix A. Appendix}

- L1: leachate sampled in May, 2006, landfill age 1.5 years.
- W1: solid samples collected from the 4th layer of landfill with the landfill age of 0.5 year.

- W2: solid samples were collected from the 1st layer of landfill with the landfill age of 1.5 years.

\section{Appendix B. Supplementary data}

Supplementary data associated with this article can be found, in the online version, at doi:10.1016/ j.chemosphere.2007.07.013.

\section{References}

Agdag, O.N., Sponza, D.T., 2005. Effect of alkalinity on the performance of a simulated landfill bioreactor digesting organic solid wastes. Chemosphere 59, 871-879.

Aulin, C.B.S., Neretnicks, I., 1997. The influence of humic substances on the long term mobility of toxic metals. In: Christensen, T.H., Cossu, R., Stegman, R. (Eds.), Proceedings Sardinia 97, Sixth International Landfill Symposium, Cagliari, Italy, CISA. Environmental Sanitary Engineering Centre, Italy, pp. 267-278.

Baumann, T., Fruhstorfer, P., Klein, T., Niessner, R., 2006. Colloid and heavy metal transport at landfill sites in direct contact with groundwater. Water Res. 40, 2776-2786.

Baun, D.L., Christensen, T.H., 2004. Speciation of heavy metals in landfill leachate: a review. Waste Manage. Res. 22, 3-23.

Benson, C.H., Barlaz, M.A., Lane, D.T., Rawe, J.M., 2007. Practice review of five bioreactor/recirculation landfills. Waste Manage. 27, 1329.

Bozkurt, S., Moreno, L., Neretmieks, I., 1999. Long-term fate of organics in waste deposits and its effect on metal release. Sci. Total Environ. 228, 135-152.

Bozkurt, S., Moreno, L., Neretnieks, I., 2000. Long-term processes in waste deposits. Sci. Total Environ. 250, 101-121.

Caine, M., Campbell, D., Santen, A.V., 1999. The landfill gas timeline: the Brogborough test cells. Waste Manage. Res. 17, 430-442.

Christensen, J.B., Botma, J.J., Christensen, T.H., 1999. Complexation of $\mathrm{Cu}$ and $\mathrm{Pb}$ by $\mathrm{DOC}$ in polluted groundwater: a comparison of experimental data and predictions by computer speciation models (WHAM and MINTEQA2). Water Res. 33, 3231-3238.

Christensen, J.B., Christensen, T.H., 2000. The effect of $\mathrm{pH}$ on the complexation of $\mathrm{Cd}, \mathrm{Ni}$, and $\mathrm{Zn}$ by dissolved organic carbon from leachate-polluted groundwater. Water Res. 34, 3743-3754.

Christensen, J.B., Jensen, D.L., Gron, C., Fulip, Z., Christensen, T.H., 1998. Characterization of the dissolved organic carbon in landfill leachate polluted groundwater. Water Res. 32, 125-135.

Clemente, R., Bernal, M.P., 2006. Fractionation of heavy metals and distribution of organic carbon in two contaminated soils amended with humic acids. Chemosphere 64, 1264-1273.

Dijkstra, J.J., Meeussen, J.C.L., Comans, R.N.J., 2004. Leaching of heavy metals from contaminated soils; an experimental and modeling study. Environ. Sci. Technol. 38, 4390-4395.

Dijkstra, J.J., van Zomeren, A., Meeussen, J.C.L., Comans, R.N.J., 2006 Effect of accelerated aging of MSWI bottom ash on the leaching mechanisms of copper and molybdenum. Environ. Sci. Technol. 40, 4481-4487.

Doig, L.E., Liber, K., 2007. Nickel speciation in the presence of different sources and fractions of dissolved organic matter. Ecotox. Environ. Safe. 66, 169-177.

Erses, A.S., Onay, T.T., 2003. In situ heavy metal attenuation in landfills under methanogenic conditions. J. Hazard. Mater. 99, 159-175.

Evangelou, M.W.H., Ebel, M., Schaeffer, A., 2007. Chelate assisted phytoextraction of heavy metals from soil. Effect, mechanism, toxicity, and fate of chelating agents. Chemosphere 68, 989-1003. 
Fan, H.J., Shu, H.Y., Yang, H.S., Chen, W.C., 2006. Characteristics of landfill leachates in central Taiwan. Sci. Total Environ. 361, 2537.

Feng, S.L., Wang, X.M., Wei, G.J., Peng, P.G., Yang, Y., Cao, Z.H., 2007. Leachates of municipal solid waste incineration bottom ash from Macao: heavy metal concentrations and genotoxicity. Chemosphere 67, 1133-1137.

Filip, Z., Cheshire, M.V., Goodman, B.A., McPhail, D.B., 1985. The occurrence of copper, iron, zinc and other elements and the nature of some copper and iron complexes in humic substances from municipal refuse disposed of in a landfill. Sci. Total Environ. 44, 1-16.

Flyhammar, P., 1997. Estimation of heavy metal transformations in municipal solid waste. Sci. Total Environ. 198, 123-133.

Flyhammar, P., Håkansson, K., 1999. The release of heavy metals in stabilised MSW by oxidation. Sci. Total Environ., 291-303.

Franson, M.A.H., 1998. Standard Methods for the Examination of Water and Wastewater. American Public Health Association, Washington.

González-Vila, F.J., Bautista, J.M., Rio, J.C.D., Martin, F., 1995. Evolution of chemicals within the dump profile in a controlled landfill. Chemosphere 31, 2817-2825.

Gondar, D., López, R., Fiol, S., Antelo, J.M., Arce, F., 2006. Cadmium, lead, and copper binding to humic acid and fulvic acid extracted from an ombrotrophic peat bog. Geoderma 135, 196-203.

Gounaris, V., Anderson, P.R., 1993. Characteristics and environmental significance of colloids in landfill leachate. Environ. Sci. Technol. 27, $1381-1387$.

Guibaud, G., Tixier, N., Bouju, A., Baudu, M., 2003. Relation between extracellular polymers composition and its ability to complex $\mathrm{Cd}, \mathrm{Cu}$ and $\mathrm{Pb}$. Chemosphere 52, 1701-1710.

Gustafsson, J.P., Berggren, K.D., 2005. Modeling salt-dependent proton binding by organic soils with the NICA-Donnan and Stockholm Humic models. Environ. Sci. Technol. 39, 5372-5377.

Hater, G., Green, R., Vogt, G., Davis-Hoover, W., Carson, D., Thorneloe, S., Kremer, F., 2003. Landfills as Bioreactors: Research at the Outer Loop Landfill, Louisville, Kentucky. US Environmental Protection Agency, Cincinnati, Ohio.

He, P.J., Qu, X., Shao, L.M., Li, G.J., Lee, D.J., 2007. Leachate pretreatment for enhancing organic matter conversion in landfill bioreactor. J. Hazard. Mater. 142, 288-296.

He, P.J., Shao, L.M., Qu, X., Li, G.J., Lee, D.J., 2005. Effects of feed solutions on refuse hydrolysis and landfill leachate characteristics. Chemosphere 59, 837-844.

He, P.J., Xiao, Z., Shao, L.M., Yu, J.Y., Lee, D.J., 2006a. In-situ distributions and characteristics of heavy metals in full-scale landfill layers. J. Hazard. Mater. 137, 1385-1394.

He, P.J., Xue, J.F., Shao, L.M., Li, G.J., Lee, D.J., 2006b. Dissolved organic matter (DOM) in recycled leachate of bioreactor landfill. Water Res. 40, 1465-1473.

Huang, J.S., Wu, C.S., Chen, C.M., 2005. Microbial activity in a combined UASB-activated sludge reactor system. Chemosphere 61, 1032-1041.

Jensen, D.L., Ledin, A., Christensen, T.H., 1999. Speciation of heavy metals in landfill-leachate polluted groundwater. Water Res. 33, 26422650.
Kjeldsen, P., Barlaz, M.A., Rooker, A.P., Baun, A., Ledin, A., Christensen, T.H., 2002. Present and long-term composition of msw landfill leachate: a review. Crit. Rev. Environ. Sci. Tecnol. 32, 297-336.

Krishnamurti, G.S.R., Naidu, R., 2002. Solid-solution speciation and phytoavailability of copper and zinc in soil. Environ. Sci. Technol. 36, 2645-2651.

Kyziol, J., Twardowska, I., Schmitt-Kopplin, P.H., 2006. The role of humic substances in chromium sorption onto natural organic matter (peat). Chemosphere 63, 1974-1982.

Li, G.K., Sang, N., Guo, D.S., 2006. Oxidative damage induced in hearts, kidneys and spleens of mice by landfill leachate. Chemosphere 65, 1058-1063.

Lu, J.C.S., Eichenberger, B., Stearns, R.J., 1985. Leachate From Municipal Landfills - Production and Management. Noyes Publications, Park Ridge, NJ.

Mårtensson, A.M., Aulin, C., Wahlberg, O., Ågren, S., 1999. Effect of humic substances on the mobility of toxic metals in a mature landfill. Waste Manage. Res. 17, 296-304.

Mecozzi, M., Pietrantonio, E., 2006. Carbohydrates proteins and lipids in fulvic and humic acids of sediments and its relationships with mucilaginous aggregates in the Italian seas. Mar. Chem. 101, 27-39.

Øygard, J.K., Måge, A., Gjengedal, E., 2004. Estimation of the massbalance of selected metals in four sanitary landfills in Western Norway, with emphasis on the heavy metal content of the deposited waste and the leachate. Water Res. 38, 2851-2858.

Reinhart, D.R., Al-Yousfi, B.A., 1996. The impact of leachate recirculation on municipal solid waste landfill operating characteristics. Waste Manage. Res. 14, 337-346.

Reinhart, D.R., McCreanor, P.T., Townsend, T., 2002. The bioreactor landfill: its status and future. Waste Manage. Res. 20, 172-186.

Sawalha, M.F., Peralta-Videa, J.R., Saupe, G.B., Dokken, K.M., GardeaTorresdey, J.L., 2007. Using FTIR to corroborate the identity of functional groups involved in the binding of $\mathrm{Cd}$ and $\mathrm{Cr}$ to saltbush (Atriplex canescens) biomass. Chemosphere 66, 1424-1430.

Schwab, A.P., He, Y.H., Banks, M.K., 2005. The influence of organic ligands on the retention of lead in soil. Chemosphere 61, 856-866.

Shirshova, L.T., Ghabbour, E.A., Davies, G., 2006. Spectroscopic characterization of humic acid fractions isolated from soil using different extraction procedures. Geoderma 133, 204-216.

State Environmental Protection Administration of China, 1997. Standard for pollution control on the landfill site for domestic waste. GB168891997. State Environmental Protection Administration of China, Beijing, China.

Thurman, E.M., Malcolm, R.L., 1981. Preparative isolation of aquatic humic substance. Environ. Sci. Technol. 15, 463-466.

van der Sloot, H.A., van Zomeren, A., Meeussen, J.C.L., Seignette, P., Bleijerveld, R., 2007. Test method selection, validation against field data, and predictive modelling for impact evaluation of stabilised waste disposal. J. Hazard. Mater. 141, 354-369.

Ward, M.L., Bitton, G., Townsend, T., 2005. Heavy metal binding capacity (HMBC) of municipal solid waste landfill leachates. Chemosphere 60, 206-215.

Wu, J., West, L.J., Stewart, D.I., 2002. Effect of humic substances on $\mathrm{Cu}(\mathrm{II})$ solubility in kaolin-sand soil. J. Hazard. Mater. 94, 223-238. 